\title{
“THE INITIATED”: AARON DIRECTOR AND THE CHICAGO MONETARY
}

\author{
TRADITION
}

\author{
BY GEORGE S. TAVLAS*
}

\begin{abstract}
Aaron Director taught at the University of Chicago from 1930 to 1934 and from 1946 to 1967. Both periods corresponded to crucial stages in the development of Chicago monetary economics under the leaderships of Henry Simons and Milton Friedman, respectively. Any impact that Director may have played in the development of those stages and to the relationship between the views of Simons and Friedman has been frustrated by Director's lack of publications. I provide evidence, much of it for the first time, showing the important role played by Director in the development of Chicago monetary economics, including his role as a transmitor of Simons's ideas to Friedman.
\end{abstract}

* Bank of Greece and the Hoover Institution, Stanford University Email address: gtavlas@bankofgreece.gr

This "preprint" is the peer-reviewed and accepted typescript of an article that is forthcoming in revised form, after minor editorial changes, in the Journal of the History of Economic Thought (ISSN: 1053-8372), issue TBA. Copyright to the journal's articles is held by the History of Economics Society (HES), whose exclusive licensee and publisher for the journal is Cambridge University Press. (https://www.cambridge.org/core/journals/journal-of-the-history-of-economicthought) This preprint may be used only for private research and study and is not to be distributed further.

The preprint may be cited as follows:

Tavlas, George S. "The Initiated": Aaron Director and the Chicago Monetary Tradition. Journal of the History of Economic Thought (forthcoming). Preprint at SocArXiv, osf.io/preprints/socarxiv 


\section{INTRODUCTION}

Aaron Director has long been a revered, but enigmatic, figure in the development of economics at the University of Chicago. Director taught in Chicago's economics department from 1930 to 1934 and, after spending most of the intervening years working for the U.S. government, taught in the Law School from 1946 until his retirement in 1965. His legacy as a revered figure stems mainly from his time at the Law School, where he played a key role in establishing the field of law and economics as a separate discipline and, in 1958, founded The Journal of Law and Economics. ${ }^{1}$ His reputation as an enigmatic figure reflects the fact that he left very little behind in terms of a written track record through which to assess his contributions. During his career in the Law School, his views became known through his teaching. His influence on the profession was revealed in the writings of his students, many of whom became distinguished legal scholars, and through his influence on Law School colleagues. ${ }^{2}$ As George Stigler put it, "most of Aaron's articles have been published under the names of his colleagues" (quoted from University of Chicago News Office 2004, p. 2).

Director's published output in the area of monetary economics was, if anything, even sparser than his published writings on law and economics. In the area of monetary economics, he had only four substantive publications: a 1931 book, The Problem of Unemployment, co-authored with Paul Douglas; a forty-five page monograph, Unemployment, published in 1932; a twenty-seven page monograph, The Economics of Technocracy, published in 1933; and a 1940 article, "Does Inflation Change the Economic Effects of War?," published in the American Economic Review (AER), that dealt with the appropriate monetary framework for a war economy. Director also signed several Chicago departmental memoranda, circulated in 1932 and 1933, which laid out

\footnotetext{
${ }^{1}$ A press release issued by the University of Chicago upon Director's death in 2004 referred to him as "founder of the field of Law and Economics" (University of Chicago News Office 2004, p. 1). Ronald Coase, who became co-editor with Director of The Journal of Law and Economics in 1964, expressed the view that "Director played an important, perhaps crucial, role in the emergence of that new subject, law and economics, in the United States" (Coase 1998, p. 601).

${ }^{2}$ See Coase (1998). In an essay on the development of Chicago economics, Reder (1982, p. 7) wrote: "In preparing this essay, I have been struck by the many strong expressions of intellectual indebtedness both of Chicago economists and legal scholars (such as Edward Levi and Robert Bork) to Aaron Director.... Director appears to have exercised a great deal of influence upon the principal figures in Chicago economics from the 1930 s to the present."
} 
the Chicago analysis of the business cycle and its preferred policy responses to the Great Depression. Following Director's return to Chicago in 1946, he published nothing on the subject of money apart from a 1948 letter that appeared in the New York Times. ${ }^{3}$

The scarcity of Director's published writings in monetary economics is regrettable because his two appointments at the University of Chicago coincided with crucial stages in the development of Chicago monetary economics and because of Director's personal intimacy with the two leading figures underpinning those stages. Director's initial stint at Chicago from 1930 to 1934 coincided with the emergence of the Chicago monetary tradition in the early-1930s under the leadership of Henry Simons. That tradition stressed the role of an unstable velocity of circulation of money in initiating the business cycle, the perverse role played by a fractional-reserve banking system in exacerbating the cycle, the need of money-financed fiscal deficits to combat the cycle, and the necessity of both a monetary rule -- either a stable-price-level rule or a fixed-quantityof-money rule -- and 100 percent reserves on demand deposits to help achieve long-run economic stability. Until the time of Simons's death in 1946, Director and Simons had been the best of friends (Coase 1998, p. 602). Director's second stint at the University of Chicago, beginning in 1946, coincided with Milton Friedman's appointment to Chicago's economics faculty and with the emergence of Friedman's monetarist framework from the late-1940s to the mid-1950s. That framework featured the functional stability of the demand for money, a monetary interpretation of the business cycle in general and the Great Depression in particular, and a constant-money-supplygrowth rule for long term stability; the framework also called for 100 percent reserve requirements, but not as a prerequisite for economic stability. As was the case with Director and Simons, Director and Friedman were intimate friends. Director was Friedman's brother-in-law -- Friedman having married Director's sister, Rose; the two brothers-in-law had a close personal relationship (Friedman and Friedman 1998, Chapter 14). ${ }^{4}$

\footnotetext{
${ }^{3}$ The letter was co-signed with seven other University of Chicago colleagues. I discuss the contents of the letter below.

${ }^{4}$ George Stigler stated the following about Friedman's reaction to Director's lack of published output: "Milton Friedman was always chiding -- to use a mild word -- his brother-in-law for not writing his ideas up. 'It belongs in the public domain,' he said, and 'if you don't write anything, you've got it coming.' If quality is an increasing function of time, this was method by which you create pearls, but it didn't work in this case" (quoted in Kitch 1983, p. 203).
} 
In addition to his close relationships with Simons and Friedman, Director also interacted closely with other members of the economics departments during his stints at Chicago. During the early-1930s members of the University of Chicago's economics faculty, including Director, met regularly in departmental meetings and Sunday social gatherings at Frank Knight's home to discuss the causes of the Great Depression and to formulate policy responses to the Depression (Tavlas 2019a). Following his appointment to the Law School, Director "was responsible for generating a great deal of interaction among members of the Law School Faculty, the Economics Department, and the Business School"; he also participated in, and occasionally hosted, "bull sessions" among members of the economics faculty (Milton Friedman, quoted from Friedman and Friedman 1998, pp. 194-95).

Having been at the University of Chicago during two crucial stages of the development of monetary economics at that institution, having had close personal relations with the two leading figures of each of those stages, and having participated in regular discussions among members of the economics departments during those stages, Director was in a unique position to shed light on the relationship between the monetary frameworks of those stages. Professional interest in that relationship stemmed from Friedman's (1956a) claim that his monetary framework was an outgrowth of a 1930s and 1940s Chicago oral quantity-theory tradition, which "differed sharply from the atrophied and rigid caricature [of the quantity theory] that is so frequently described by the proponents of the new income-expenditure approach.... At Chicago, Henry Simons and Lloyd Mints directly, Frank Knight and Jacob Viner at one remove, taught and developed a more subtle and relevant version [of the quantity theory]" (1956a, p. 3). That claim led to a long-running debate about the nature of the Chicago monetary tradition and its relationship to Friedman's monetary economics. An upshot of that debate as it stood in the early-1970s was that Friedman was accused of having "invented" a University of Chicago quantity theory tradition in order to launch a successful monetarist counter-revolution against the then-ruling Keynesian orthodoxy, an issue to which I return in the concluding section. ${ }^{5}$ Although Director's stays at

\footnotetext{
${ }^{5}$ The charge that Friedman had "invented" a University of Chicago monetary tradition was made by Johnson (1971, pp. 10-11). The debate about the relevance of the earlier Chicago monetary tradition to Friedman's monetary framework had the effect of calling into question Friedman's professional integrity. Leeson (2003) edited a two-volume set that reprinted articles dealing with the debate on the earlier
} 
Chicago bridged the two periods of dominance of Chicago monetary economics by Simons and Friedman, respectively, Director did not leave behind his view on the relationship of the monetary economics of those two Chicagoans in published work; nor did he leave behind published commentary on the role that he may have played in influencing the views of Simons and/or Friedman or on the influence of those two economists on his views. ${ }^{6}$

In this paper, I provide evidence that makes Director's role in the development of both stages of Chicago monetary economics less enigmatic. In particular, I show the close correspondence between (i) Director's analysis of the mechanics of the business cycle and his proposed policy response to the cycle, as provided in his three aforementioned publications of the early-1930s, and (ii) the views that are known to have characterized the earlier Chicago monetary tradition. I show that Director brought those views, especially the emphasis on the important role played by the quantity of money in the economy and the need of policy rules, with him in his second stint at Chicago. In this connection, I discuss the contents of three hitherto undiscovered works by Director: two unpublished 1955 memoranda and a 1956 lecture (which is available as an online appendix to this article). In those works, Director emphasized the role of money in the economy and assessed alternative monetary rules, giving credit to Simons for having established the case in favor of rules. I show that Director advocated a constant money-supply-growth-rate rule in 1955, one year before Friedman publicly did so, with the implication that there had been cross-fertilization between Friedman's formulation of a monetary-growth rule and that of Director. Like Friedman, Director also blamed the Fed for causing the Great Depression. Finally, I show that Director supported the 100 percent reserves scheme in the mid-1950s, although, like Friedman at that time, he did not view the scheme as essential for stabilizing the economy.

\section{BIOGRAPHICAL SKETCH ${ }^{7}$}

\footnotetext{
Chicago monetary tradition and its possible influence on Friedman's monetary economics. For a detailed discussion of the earlier Chicago monetary tradition, see Tavlas (2019a).

${ }^{6}$ Director's lack of published output likely accounts for Friedman's not having named Director as one of the members of the earlier Chicago monetary tradition.

${ }^{7}$ This section draws on Coase (1998), Friedman and Friedman (1998), Stephen Stigler (2005), Van Horn (2010a; 2010b), and University of Chicago catalogs for various academic years contained in the University’s Special Collections Research Center.
} 
Aaron Director was born in 1901 in Charterisk, Ukraine, which was then part of the Russian empire. At the time, his father worked in a flour mill. The mill failed on two occasions; following each of those events, his father emigrated alone to Portland, Oregon. Shortly after the second time, in early 1914, his father sent for the rest of his family.

Director graduated from Lincoln High School in Portland in 1921 and, along with fellow student, Mark Rothkowitz (who would later become a famous abstract painter under the name of Mark Rothko), was admitted to Yale on a scholarship. ${ }^{8}$ After graduating from Yale (in three years), Director worked in various jobs, including farm worker, coal miner, and teacher at the Newark Labor College. An interest in worker's education led him to Europe (on a cattle boat) to study the education of adult workers. He returned to the United States to teach at Portland Labor College, run by the Oregon Federation of Labor.

In 1927, Director entered the University of Chicago as a graduate student to study labor economics with Douglas, who had offered him a fellowship. In 1930, Director was made an instructor in the economics department, where he taught courses on Labor Problems (Econ 240) and Introduction to Statistics (Econ 211). During the early-1930s, his interest gravitated away from labor economics toward monetary economics. This circumstance was noted in a January 31, 1934 letter from Harry Millis, who was Chair of the Economics Department, to Viner; Millis complained that in his course on labor problems, Director had "come to the conclusion that there was nothing worth the while to talk about except monetary theory and policy and business cycles" (quoted from Van Horn 2010a, p. 266). Director was evidently a very effective teacher. Paul Samuelson wrote of his experience as an undergraduate at Chicago in the early-1930s as follows: "I had learned my first economics from Aaron Director, who had a tremendous impact on me" (letter from Samuelson to Milton Friedman, December 8, 1995).

In the years leading up to 1934, Director came increasingly under the influence of Knight, who had become embroiled in a bitter, personal altercation with Douglas. One consequence of this altercation was that Douglas refused to support the renewal of Director's contract. Douglas's justification was that Director had not established a strong publishing record. As a result of Douglas's opposition, in 1934 Director's

\footnotetext{
${ }^{8}$ At Yale, Director and Rothko published a left-leaning newspaper called the Saturday Evening Pest.
} 
teaching contract was not renewed. ${ }^{9}$ He moved to the U.S. Treasury for two years, before starting work on a dissertation under Viner on the quantitative history of the Bank of England. Director traveled to England in 1937 to conduct research on the dissertation, but was denied access to the Bank's records by the Bank's officials. ${ }^{10}$ Following his return from England, he spent the fall semester of 1938 at the University of Chicago, where he worked on his thesis and actively engaged in discussions with members of the economics department. ${ }^{11}$ However, he never completed his dissertation. He returned to Washington where he worked at the Brookings Institution and several government agencies until the end of World War II.

Following the death of Simons in 1946, apparently by suicide (Rose Friedman, from Friedman and Friedman 1998, p. 155; Van Horn 2014), Director agreed to take a position in the Chicago Law School. In addition to his teaching responsibilities, Director headed the Free Market Study Project, financed by the William Volker Fund, which promoted free-market research. The proposal that Director head the Project at the Law School had been pushed forward by Simons and Hayek. ${ }^{12}$ After Simons's death, and following the offer made to Director to join the Law School, Hayek wrote to Director encouraging him to accept the offer with the following argument: "It seems to me the only chance that the tradition which Henry Simons created will be kept alive and continued in Chicago" (letter from Hayek to Director, July 10, 1946; quoted from Van Horn 2010, p. 267). After his retirement from the Chicago Law School in 1965, Director moved to California, where he worked at the Hoover Institution and the Law School at Stanford University. Director died in 2004.

\footnotetext{
${ }^{9}$ For a discussion, see Tavlas (2019a).

${ }^{10}$ While in England, Director befriended Friedrich Hayek (Van Horn 2010a, p. 266).

${ }^{11}$ This information is contained in a February 1939 letter from Simons (also writing on behalf of Knight and Mints) to Department Chair Chester Wright. Simons wrote: "When he [Director] was back in the fall, I acquired again the delightful feeling of belonging to a real (and rather numerous) community of economists hereabouts." (Letter from Simons to Wright, February 20, 1939). The letter was an (unsuccessful) attempt to have Simons reappointed to the faculty.

12 The proposal by Hayek and Simons that Director be offered the position in the Law School to head the Free Market Study Project was initially turned down by the Law School's administration. Van Horn (2014) provided evidence supporting the view that Simons's apparent suicide was connected with the initial decision not to approve the proposal.
} 


\section{THE 1930s CHICAGO MONETARY TRADITION AND DIRECTOR}

\section{III.1. The Chicago Tradition}

As mentioned, Chicago economists circulated several departmental memoranda in the early-1930s in which they laid out their business-cycle theory and policy framework. Three of these memoranda were particularly important in providing the Chicago tradition's positions. ${ }^{13}$

April 1932 Memorandum (Pettengill 1932). The untitled memorandum, addressed to Congressman Samuel Pettengill, was three pages in length. The memorandum dealt with business-cycle theory and counter-cyclical policy; it was signed by twelve Chicagoans, including Director. ${ }^{14}$

March/April 1933 Memorandum (Knight et al. 1933). The untitled memorandum was five pages in length. It proposed both long-term banking reform, introducing the 100 percent reserves scheme, and short-term measures to reverse the economic contraction and deal with the collapse of the banking system. Knight and Simons were the progenitors of the banking reform measures, which were based on the English Bank Charter Act of $1844 .{ }^{15}$ Eight Chicagoans, including Director, signed the memorandum. ${ }^{16}$

November 1933 Memorandum (Simons et al. 1933). This document was titled "Banking and Currency Reform" and was fourteen-and-one-half pages in length; it included a five-and-one-half page appendix, "Banking and Business Cycles," and a seven-page supplementary memorandum, "Long-time Objectives of Monetary

\footnotetext{
13 The Chicagoans issued a total of five memoranda in 1932 and 1933 that addressed the causes of, and policy responses to, the Great Depression. Two of these memoranda are not discussed in this paper. (1) A January 1932 memorandum sent to President Hoover that was signed by both Chicagoans and nonChicagoans. (2) An early-1933 document that sharply criticized the fiscal tightening in the budget announced by President Hoover in December 1932. For discussions of the contents of the latter two documents, see Tavlas (2019b).

14 The other signatories were: Department Chair Millis, Douglas, Knight, Mints, Simons, Viner, Garfield Cox, Harry Gideonse, Henry Schultz, Chester Wright, and Theodore Yntema.

15 See Tavlas (2020).

16 The other signatories were Cox, Douglas, Knight, Mints, Schultz, Simons, and Albert Hart. The memorandum was originally circulated to about forty academics and Washington politicians. It went through two revisions -- in March and April 1933, respectively.
} 
Management." 17 It was drafted by Simons, with considerable input from Director. In a letter to Douglas, Simons, responding to a query from Douglas about who drafted the (unsigned) November 1933 memorandum, wrote: “Actually I did write the thing alone; but it would never have been written except for my conversations with other people, Mr. Director especially...." (letter, Simons to Douglas, October 2, 1934).

Analytic framework. The key theoretical characteristics of the 1930s Chicago tradition were the following. ${ }^{18}$ (i) The earlier Chicagoans used Irving Fisher's equation of exchange, $M V+M^{\prime} V^{\prime}=P T$, where $M$ is the quantity of money, $V$ is the velocity of circulation of money, $M^{\prime}$ is the quantity of demand deposits (or near moneys), $V^{\prime}$ is the velocity of circulation of demand deposits, $P$ is the average price level of the considerations traded for money, and $T$ is the annual physical volume of these considerations. The Chicagoans argued that economic fluctuations are caused by sharp, autonomous variations in $V$. (ii) Changes in $V$ have a cumulative effect on prices and on real economic activity. Once prices start to rise, they trigger anticipations of further prices rises. Thus, if individuals expect prices to rise, they will dishoard (i.e., increase the velocity of circulation, $V$ ). (iii) The costs faced by businesses, especially wages and interest rates, are sticky. Hence, with changes in costs lagging changes in prices, price increases initially affect profits and output. (iv) The effects of cumulative changes in $V$ are greatly exacerbated by the perverse behavior of a fractional-reserve banking system, which expands credit -- and, thus, demand deposits, or $M^{\prime}$-- in booms and contracts credit in depressions. As a result, the quantity of near-moneys $\left(M^{\prime}\right)$ and the velocity of near-moneys $\left(V^{\prime}\right)$ increase in booms and contract in depressions. (v) Because of the foregoing factors, the economic system is essentially unstable and there is no bottom to a depression.

Policy framework. What especially distinguished the earlier Chicago tradition from other approaches to the quantity theory in the 1930s was Chicago's policy edifice. It consisted of two pillars -- one involving counter-cyclical policies and the other policies

\footnotetext{
${ }^{17}$ Phillips (1995, p. 74) reported that the November memorandum was more-widely distributed than the March memorandum.

${ }^{18}$ For documentation, see Patinkin (1969) and Tavlas (1997; 2019a).
} 
for long-term economic stability.

Counter-cyclical policies. Anti-depression policy, the Chicagoans believed, requires an expansion in $M$. The necessary variation in $M$ can be generated by either open-market operations or money-financed fiscal deficits. During depressions, policies operating through the banking system are not likely to be effective, in part, because, during periods of low confidence, banks do not want to lend, and businesses do not want to borrow. The most effective way to put money into circulation is through moneyfinanced fiscal deficits.

Long-term stability. To stabilize the perverse behavior of a fractional reserve banking system, the earlier Chicagoans favored 100 percent reserve requirements on demand deposits, an idea that became known as the Chicago Plan of Banking Reform (Hart 1935). The idea aimed to (1) eliminate the possibility of losses by depositors, thereby helping to prevent abrupt shifts from deposits into currency (due to the loss of confidence), (2) provide better control of the money supply, and (3) prevent the socialization of the bank-lending function and political control over investment. To reduce policy uncertainty and to moderate the business cycle, the Chicagoans believed that monetary policy should be conducted on the basis of a rule -- ideally a rule that fixes the quantity of money; a second-best rule would be one that stabilizes the price level. ${ }^{19}$ The November 1933 memorandum presented six possible rules, including a monetarygrowth rule, a fixed-quantity-of-money rule, and a price-level-stabilization rule. Although the memorandum came out in favor of a rule that fixes the quantity of money, the memorandum emphasized that what is important is the adoption of a precise rule to reduce uncertainty rather than the choice among alternative rules. To help ensure that domestic objectives could be achieved, the Chicagoans called for the abandonment of the gold standard and for a move to a more-flexible exchange-rate system.

\section{III.2. Director in the Early-1930s}

The following summary of Director's business-cycle analytics and policy views is based on Douglas and Director (1931), and Director (1932; 1933). Douglas and

\footnotetext{
${ }^{19}$ The preference for a rule that fixes the quantity of money was stated in the November 1933 memorandum. In Tavlas (2019c), I argue that the November memorandum marked the origination of the debate on rules vs. discretion. The November 1933 memorandum was published in 1994, in Archival Supplement 4 to Research in the History of Economic Thought and Methodology.
} 
Director's 1931 book The Problem of Unemployment, was primarily written in the summer of 1930, during which time both co-authors stayed at Swarthmore College; given Douglas's seniority, Director regarded it as generous of Douglas to include his name as co-author. ${ }^{20}$ I conjecture that the 1933 monograph, The Economics of Technocracy, was completed at the very end of 1932 or the beginning of 1933 . The conjecture is based on the following: (1) the latest citation in the monograph (p. 5) is to a December 28, 1932 article published in The Nation, and (2) the monograph was published under the University of Chicago's Public Policy Pamphlets series, then-edited by Harry Gideonse; Gideonse's “Introduction” to Director's contribution was dated February 2, 1933. Consequently, all three publications by Director preceded the appearance of the March 1933 memorandum, which introduced the idea of 100 percent reserve requirements.

Analytical framework. Director believed that there are many initiating causes of the cycle; there is no way of isolating any specific cause (Director and Douglas 1931, p. 168; Director 1932, p. 24). ${ }^{21}$ At the bottom of a cycle, banks hold large amounts of reserves, costs have declined, stocks have been depleted, and less-efficient workers have been eliminated (Director and Douglas 1931, pp. 169-70; Director 1932, pp. 24-25). Eventually, optimism begins to take hold, and the expansionary phase of the cycles begins. Using the $M V+M^{\prime} V^{\prime}=P T$ framework, the banking system plays a crucial role in the cycle (Director and Douglas 1931, p. 236; Director 1932, p. 24; Director 1933, pp. 19, 23). The expansion proceeds as follows. (i) The demand for credit rises; the large amount of reserves held by the banks supports an expansion of credit to meet the higher demand (Director and Douglas 1931, p. 169; Director 1932, pp. 24-25; Director 1933, p. 22). (ii) Confidence rises and prices begin to increase, but not equally;

20 This information is based on a 1996 conversation between Friedman and Director. Friedman communicated the information to David Laidler, in a letter dated October 9, 1996 (Friedman 1996). Director's attribution of generosity to Douglas reflected Director's humility. In a 1934 letter from Douglas to Chester C. Maxey (who taught economics at Whitman College), Douglas wrote about Director as follows "During the year 1929-1930 he was my research assistant. We worked together at Swarthmore College under the auspices of the Swarthmore Unemployment Study for six months in 1930, and wrote jointly the book The Problem of Unemployment. He was an equal author in every respect" (letter from Douglas to Maxey, October 29, 1934).

${ }^{21}$ Director (1933 p. 21) attributed the Great Depression to the debts imposed on the defeated countries following World War I and to tariff increases. 
wages and interest costs lag behind, and, therefore, profits, output, and employment rise (Director 1932, pp. 25-26; Director 1933, p. 22). ${ }^{22}$ (iii) The increase in prices gives rise to expectations of further price increases and a "cumulative process" involving higher prices, still-higher price expectations, and so on, ensues (Director and Douglas 1931, p. 182; Director 1932, pp. 36-37). (iv) Expectations of higher prices along with sticky factor costs give rise to expectations of still-higher profits. As a result, banks expand credit $\left(M^{\prime}\right)$ further (Director and Douglas 1931, p. 171). (v) Two "tendencies" which reverse the expansion emerge: (a) banks reserve ratios decline so that banks raise interest rates and decrease the supply of loans, and (b) the increases in wages and other costs catch-up with the rise in prices, decreasing profits (Director 1932, p. 26). (vi) Once a depression starts, there is no bottom to the fall in output: "There is no certainty of recovery from a widespread and serious depression .... [T] here is always the possibility of a complete breakdown of our economic organization and hence the great importance of any action to check the violent fluctuations in economic activity" (Director 1932, p. 28).

Counter-cyclical policies. Director believed that control over the quantity of money needed to play a key role in "eliminating or reducing industrial fluctuations" (Director 1932, p. 37). He argued that "the most significant line of action is that to be taken by central banks -- the Federal Reserve System -- in the United States" (Director 1932, p. 37). He also argued that: "If the banks act promptly enough, they can so regulate the volume of bank credit [demand deposits] as to check any boom which develops, and counteract any depression which begins" (Director 1932, p. 38).

In Douglas and Director (1931), the authors assessed various methods of increasing the supply of money. They considered indirect methods -- that is, open-market operations or a lowering of the discount rate -- unlikely to be effective during depressions because "it is not certain that the reduction in cost [i.e., lowering of interest rates] will be sufficient to induce businessmen to take full advantage of it in view of the increasing unprofitableness of business" (p. 245; see, also, Director 1932, p. 38). Therefore, they opted for "more direct methods for seeing to it that the increased

\footnotetext{
${ }^{22}$ Director believed that prices play a key role in coordinating economic activity. He stated: "It is essential to point out that in a capitalistic society the stimulus to economic activity is the making of profits, and the mechanism for coordinating economic behavior of a countless number of businessmen is the pricing process" (1932, p. 23).
} 
potential credit is actually put into circulation so that in can buoy up prices" (p. 245). Specifically, Douglas and Director advocated public-works projects, preferably financed by "the issuance of added money by the government rather than by taxes" ( $p$. 248; see, also, Director 1932, pp. 36-37).

Long-term stability. Douglas and Director (1931) introduced the view that rules are preferred over discretion into the Chicago literature. In this regard, after assessing Irving Fisher's compensated-dollar proposal, they criticized the proposal for being "tied up with the consequences of the future gold production of the world" (p. 235). ${ }^{23}$ Nevertheless, Douglas and Director argued that 'Professor Fisher's proposal has the merit of being automatic and not depending on the discretion of government or banking officials" (p. 235). As mentioned, the mechanism that underpinned cyclical dynamics in Douglas and Director $(1931)$ and Director $(1932 ; 1933)$ was the effect of changes in the price level -- with sticky costs -- on profits and production. To stabilize the price level, and thus output, Douglas and Director proposed a monetary-growth rule: "If the supply of money and credit were to increase commensurately with the increase in production, the price level would be held constant and the goods produced would be sold at prices which would permit industry to go on with undiminished profits and without curtailment of activity" (1931, p. 183). The authors expressed the view that a rule aimed at stabilizing the domestic price level entailed the abandonment of the gold standard and the need of flexible exchange rates: "It is thus possible for one nation to stabilize its price level ... if it is willing to go off the gold exchange standard and allow its exchanges to fluctuate" (1931, p. 251).

\section{III.3. Discussion}

The following points merit comment. First, there were clear similarities between both the analytic and policy frameworks of Director in the early-1930s and those contained in the 1932 and 1933 Chicago memoranda. Second, although Director did not advocate the 100 percent reserves scheme in his own work during the early-1930s, he called for a reform of the monetary system (1933, p. 27) and signed the March 1933

\footnotetext{
${ }^{23}$ Fisher introduced the compensated-dollar scheme in his Purchasing Power of Money (1911) as a means of stabilizing the general price level. Under the scheme, the monetary base would consist of gold-bullion certificates, which would be convertible into a varying amount of gold linked to a general level of prices. Whenever the price level, for example, exceeded that of a given price index comprised of commodities in a certain period, the price of gold would be reduced by the same percentage in the next period.
} 
memorandum that first put forward the 100 percent reserves scheme. Third, while the book co-authored by Douglas and Director was a collaborative effort, some of the policy views set-forth in that book -- namely, the advocacy of a monetary-growth rule to maintain economic stability and money-financed fiscal deficits to combat depressions had been proposed by Douglas in an earlier paper (Douglas 1927). Hence, Douglas originated those two characteristics that came to mark the early-1930s Chicago policy framework. Fourth, prior to the 1931 book co-authored with Director, Douglas had not framed the issue of a rule in terms of a comparison of rules versus discretion. In the formation of Chicago monetary economics in the early-1930s, the argument that rules are preferable to discretion originated with both Douglas and Director.

\section{LATER VIEWS}

\section{IV.1. 1940 AER Paper}

Director's paper, "Does Inflation Change the Economic Effects of War?" dealt with the means of financing a "transfer to government of the necessary funds for the acquisition of a given fraction of current output" that was be expected to take place during the adjustment from a peacetime to a war economy (1940, p. 343). Director began with the assumption that a war-time economy would lead to full-employment, with a build-up of inflationary pressures. ${ }^{24}$ Under such conditions, what "monetary framework" should the authorities follow? Director answered: “A given criterion, such as a stable price level or fixed quantity of money, may therefore be adopted...." (1940, p. 351). In the interim, to ensure that "approximately full employment is established," Director argued that "monetary policy must be oriented around the task of increasing the aggregate output of the community, as well as making a portion of it available for the war effort" (1940, p. 351). In advocating that monetary policy be assigned the role of attaining fullemployment while preventing inflation, Director acknowledged that the emphasis he placed on the use of monetary policy was out-of-fashion: "but we have generally assumed that both inflation and deflation are monetary phenomena in the sense that they could be prevented by monetary policy. The recent discrediting of monetary policy as a means of combating deflation need not concern us" (italics supplied, 1940, p. 352).

Director then turned to the issue of the transfer of resources from the private sector

\footnotetext{
${ }^{24}$ It should be recalled that Director presented his paper two years before the entry of the United States into World War II (in December 1941).
} 
to the government under the assumption of a fully-employed, war-time economy. How should the funds needed for military expenditures be obtained -- from borrowing or from taxation? Director preferred the taxation method. First, he expressed the view that "we are more likely to adhere to a policy of monetary stability if a much larger fraction of war expenditures is obtained through taxation" (1940, p. 353). Second, and in contrast to the taxation method, Director argued that "large-scale borrowing is itself likely to promote monetary expansion. Even if the central bank had both the power and inclination to maintain monetary stability, war will subordinate its own policy to that of the treasury.... But treasuries are reluctant to pay high rates of interest, both because of the increased monetary cost of waging war and because of the adverse effect of high interest rates on institutions with large holdings of fixed interest-bearing assets" (1940, p. 358). Third, borrowing to finance was expenditures can lead to "the existence of a large public debt." The larger the debt, the larger the interest payments, and, thus, the larger the transfer of income "from income recipients as a whole to those in possession of public debt" (1940, p. 3F59).

Director next discussed deficit financing during periods of unemployment, such as the situation that existed in late 1939. He advocated money-financed fiscal deficits to combat unemployment: "We should ... give further consideration to the substitution of central bank credit for public borrowing" (1940, p. 360). Director noted that "[the] opposition to the creation of money rests on the fear that the state will not exercise the necessary restraint, and that private banks will compete with the state in the creation of money, using the money created by the state as a reserve" (1940, p. 360). How could the problem of the creation of credit by the private sector be dealt with? Director recommended the imposition of 100 percent reserve requirements on the banks: "The latter difficulty [i.e., the problem posed by the creation of credit by the banks] can, however, be overcome by applying the principle of Peel's Act to the deposits created by the central bank for government war expenditures" (1940, p. 360). ${ }^{25}$

In summary, in his 1940 article Director affirmed the importance of money in the economy, called for a "criterion" in the form of a stable price level or fixed quantity of money to guide monetary policy during war-time, and advocated the 100 percent reserves scheme to counter the ability of banks to create or destroy deposits.

\footnotetext{
${ }^{25}$ Peel's Act was another name for the English Bank Charter Act of 1844, which imposed 100 percent marginal gold-reserve requirements (above a certain fiduciary issuance) on Bank of England notes.
} 


\section{IV.2. 1948 New York Times Letter}

In January 1948, Director, Friedman, and six other University of Chicago colleagues coauthored a letter titled, "Control of Prices," published in the New York Times. ${ }^{26}$ The letter made the following points. (1) Variations in the general price level are "in the main determined by variations in the quantity of money." (2) The quantity of money is dependent on the volume of reserves. (3) The Fed and the Treasury "are amply equipped with technical power to control the volume of money and, hence, the general level of prices." (4) The "greatest contribution" that monetary policy can make is "stabilization of the price level." (5) What is needed to control the general price level "is a legislative rule directing the monetary authorities to maintain stability" (Director et al., 1948).

\section{IV.3. The 1955 Memoranda}

In July 1955, Director wrote two memoranda on monetary policy, both of which were sent to John Davenport ${ }^{27}$-- a four-page memorandum, dated July 11, and a threeand-one-half-page memorandum, dated July 29. The memoranda were apparently written in response to questions addressed to Director by Davenport. Davenport was a financial journalist who graduated from Yale in 1926, two years after Director graduated. Along with Director, Friedman, Knight, and Stigler, Davenport was one of the original thirty-eight members of the Mont Pelerin Society, having attended the first meeting of the Society in 1947 (Milton Friedman, from Friedman and Friedman 1998, p. 160). Davenport had been with of Barron's Weekly from 1949 to 1954 before becoming an Assistant Managing Editor of Fortune in 1954. He was the author of the book, The U.S. Economy, published in 1964.

The economic background to the July 1955 memoranda is relevant. The money stock (M2) rose at a fairly steady rate -- 2.8. percent from June 1953 to June 1954, and 3.9 percent from June 1954 to June 1955 (Friedman and Schwartz 1963, p. 614). A recession ended in May 1954, and a robust recovery followed (Meltzer 2009, Vol. 2, Book 1, pp. 112-14). Consumer-price inflation was mildly negative in the year through

\footnotetext{
${ }^{26}$ The other signatories were Abram Harris, Frank Knight, H. Gregg Lewis, Russell Nichols, and W. Allen Wallis. Nelson (2009) deserves credit for having discovered this letter.
} 
August 1955. At the beginning of 1955, the Fed raised margin requirements on stock purchases and short sales from fifty percent to sixty percent "to prevent the recovery from being hampered by excess speculative activity" (Federal Reserve Board, Annual Report 1955, p. 84; quoted from Meltzer 2009, Vol. 2, Book 1, p. 114). Evidently, the state of the economy, including the Fed's action to raise margin requirements, prompted Davenport to ask for Director's assessment of monetary policy. Director's assessment was provided in the July 11 memorandum.

Director's appraisal of the Fed's policy stance was generally positive, although critical of the measure aimed at reducing speculative activity in the stock market. Director pointed to the steady growth in the money supply: "If the monetary authorities are now committed to a policy of increasing the supply of money by 2 to 3 percent per year, it marks a decided improvement in monetary management. Providing, of course, they adhere to this commitment and quit worrying about particular sectors of the economy" (July 11, 1955a, p. 1). With regard to the Fed's attempt to curb stock-market speculation, Director queried: "How does one know that [stock] prices are too high?" (p. 1). He expressed the view that the Fed's concern with stock-market speculation could trigger an unwarranted "general monetary contraction" (p. 2). He continued: "Facing the [contractionary] consequences of such action on the general level of activity, [the Fed] will [then] go out of [its] way to foster monetary expansion," bringing about "a general inflation" (p. 2).

Director then considered the appropriate framework for monetary policy. He asked: "What standards or rules shall it [the monetary authority] use?" (p. 3). He wrote:

[The Fed] has these alternatives.

a. Regulate the supply of money to prevent substantial changes in the level of economic activity.

b. Regulate the supply of money to prevent significant changes in the general level of prices.

c. Increase the supply of money by some given percentage per year (p. 3).

"Rule (a)", he argued, "provides more discretion than we should provide any government agency" (p. 3). While he thought that there was "little difference between rule $(b)$ and rule $(c)$," rule $(c)$, he noted, "requires no forecasting, and no discretion" (p. 
$4) .^{28}$

Director concluded his appraisal of the Fed's monetary-policy framework with a call for a monetary-growth rule and a comment on the fixed-quantity-of-money rule (cum falling price level) as contained in the November 1933 memorandum: ${ }^{29}$

A steady increase in the supply of money is required to prevent a decline of prices resulting from the growth of output due to the growth of the labor force and capital equipment, even in the absence of increases in productivity. While we could adjust ourselves to a falling price level, this would entail unnecessary strain on the economy (p. 4).

Director followed his advocacy of a monetary-growth rule with a criticism of Hayek's position on such a rule, noting that, all else equal, an increase in the supply of money would keep prices stable in the event that productivity increases. He continued: "Some people call this inflation. And Hayek and others have talked about resulting structural maladjustments with disastrous consequences. I wish I knew what they are saying" (p. 4).

The July 29 memorandum evidently represented an initiative by Director to answer queries about monetary policy that Davenport had addressed to Hayek. A handwritten note by Director to Davenport was attached to the memorandum. It read, in part, as follows:

\section{Dear John:}

I am enclosing some brief additional notes on your questions. I doubt whether Hayek will answer your questions. He has gone to Aspen for the month.... Monetary policy has been one of the bright spots of the Eisenhower administration. So you better be cautious in undermining it.

The July 29 memorandum was mainly a critique of Hayek's monetary framework. Director stated: "[Hayek] still adheres to the conclusion that inflation -- including an increase in the supply of money which because of an increase in productivity keeps

\footnotetext{
${ }^{28}$ Director did not state that rule (b), price-level targeting, involves some discretion. He was certainly aware, however, from Simons's work (1936), that price-level targeting involves discretion in the choice of a specific price index and in the use of policy instruments. Director made this point in his 1956 lecture, discussed below.

${ }^{29}$ With output rising over time, the fixed-quantity-of-money rule would entail a falling price level.
} 
general prices stable -- creates maladjustments.... But he cannot set out the mechanism which leads to his conclusion" (1955b, p. 1). ${ }^{30}$

The memorandum contains an important argument about the origins of the Great Depression that is directly related to Friedman's emerging monetarism of the 1950s. In the first-half of the 1950s, Friedman introduced and tested two hypotheses about the Federal Reserve's role in the Depression, namely that (1) the Fed initiated the Great Depression with its policy tightening in 1928 and 1929 and (2) the Fed deepened the Depression with its policies of the early-1930s. Friedman posited the second hypothesis in 1951 and confirmed it in 1954; he introduced the hypothesis that the Fed had caused the Depression in 1956 and confirmed it two years later. ${ }^{31}$ Evidently, discussions between Director and Friedman in the mid-1950s on the causes of the Great Depression had been taking place. In the July 29 memorandum, Director stated: "There was nothing wrong with the 20's except that they did not last long enough. What I just outlined is not an inaccurate account of what happened when the Board became concerned with overspeculation and brought on the depression" (p. 4).

\section{IV.4. 1956 Lecture on Full Employment Policies}

In June 1956, Director gave a series of eight lectures at the Institute of Humane Studies. Seven of the lectures dealt with issues related to the ideas of classical economists and to the issue of monopolies. However, one of the lectures, titled 'Full Employment Policies," focused on the role of money in the economy. The lecture was delivered in two parts on June 20; each part lasted approximately forty-five minutes. From the question-and-answer session towards the end of the lecture, it is clear that Hayek was in attendance. I describe the views on money expressed by Director in that lecture and I compare them with Friedman's views in the 1950s. ${ }^{32}$

\footnotetext{
${ }^{30}$ In the mid-1930s and again in 1960, in The Constitution of Liberty, Hayek argued that monetary policy should follow a "productivity norm," under which changes in the money supply would not respond to increases in real output; the money supply would respond to increases in the income velocity of money. Under this norm, increases in overall productivity, everything else remaining the same, would be accompanied by declines in the price level. Hayek published essentially nothing on monetary policy in the 1940s and 1950s. See Selgin (1999) and White (1999).

${ }^{31}$ For documentation, see Lothian and Tavlas (2018) and Nelson (2020).

32 The lecture is available at the Hoover Institution Archives as a sound recording. I have transcribed the lecture (word-for-word) into written form and made it available in the online appendix. The typed-up
} 
Director began the lecture by expressing the view that the Keynesian emphasis on the role of the government's income and expenditure policies in stabilizing economic activity -- a role that he considered incompatible with the liberal emphasis on the minimization of the government's involvement in the economy -- was giving way to a revival of interest in the role of monetary factors in the determination of short-run variations in income (p. 2). This revival of interest, he argued, directed attention to an examination of the appropriate monetary system (pp. 2-3). That system, he believed, was an exception to the liberal emphasis on reducing the role of government. Director stated that "the issuance of fiduciary currency is a natural monopoly" and should not be left unregulated: "Monetary arrangements are a necessary function of government" (p. 2 ). Once it is determined that the government has a role in the monetary system, Director argued that: "The only problem that remains is the [choice of monetary] standard that should be adopted." The liberal position, he stated, is that "discretionary authorities should be eliminated or at least minimized" (p. 3). ${ }^{33}$

Director maintained that discretionary policies cannot successfully stabilize the economy for two main reasons. First, to be successful, such policies need to have access to accurate forecasts, but there is an "inherent difficulty -- some would say, the impossibility -- of forecasting short run changes in the economy" (p. 3). ${ }^{34}$ Second, echoing the argumentation made in the November 1933 memorandum, Director stated that a basic component of successful policies is to "provide some certainty in the way of [policy] expectations" which "[discretionary policies] cannot provide" (p. 3-4). Such certainty can only be provided by a rule. What is important, he argued, is not the particular rule followed, but that the rule be complied with. At this point, Director

\footnotetext{
version of my hand-written transcription is twelve pages in length. The page numbers below refer to the typed-up version. Based on information provided by staff of the Hoover Archives, the lectures apparently were supported by the William Volker Fund.

${ }^{33}$ In a 1959 lecture (published in 1960) at Fordham University, Friedman provided a similar argument: "The production of a fiduciary currency is, at it were, a technical monopoly" (Friedman 1960, p. 7). After enumerating "the features of money that justify government intervention" in the issuance of currency -including the resource cost of a pure commodity currency, the need to enforce contracts involving promises to pay in the medium of exchange designated to be money, and the need to set limits on the amount of money issued -- Friedman argued: "Something like a moderately stable [monetary] framework seems an essential prerequisite for the effective operation of a private market economy" (1960, p. 8). See, also, Friedman (1951b).

${ }^{34}$ As Nelson (2020, Chapter 4) documents, the same argument was made by Friedman (1948).
} 
referred to Simons.

I would point out that the late Professor Simons's original emphasis was primarily on the role of stable rules [rather] than on the character of the rules themselves. There were occasions when he was inclined to argue that it really didn't make a difference what kind of monetary system you establish -- one that led to rising prices or falling prices, and so on -- but what was important was that the rules should be fixed and known in advance so that the community could rely upon them (p. 4).

Director then considered the following alternative monetary standards.

Gold standard. Its main advantages, Director stated, are "the fact that it provides a check to governmental irresponsibility," and "it removes discretion or authority." However, it contains the following problems. (1) It is costly since it entails devoting "a fraction of [the community's] resources to produce the gold necessary" to operate a monetary standard (p. 4). ${ }^{35}$ (2) While it eliminates discretionary authority, it does not stabilize expectations, which would have to be based on prospective changes in gold production. (3) It is subject to destabilizing shifts from deposits to currency -- unless there is a system of insurance on deposits or the abolition of the fractional-reserve system: "But if fractional reserves were abolished, then the cost of producing the necessary gold to continue operations on the present level of prices might not be a minor factor anymore." (4) Its successful operation depends on not only the adherence of any particular country, "but it mainly requires the adherence of other countries" (pp. 4-5).

Director's overall evaluation of the gold standard was the following: "My own conclusion is that the conditions for assuring adhence to the system are now lacking. Consequently, we can no longer say that it will provide a check to government irresponsibility" (p. 5). What is needed, he argued, is "a new religion" to replace the gold standard (p. 5). Here, the influence of Simons on Director's thinking deserves mention. In his 1936 paper, "Rules versus Authorities in Monetary Policy," Simons wrote:

In a free-enterprise system we obviously need highly definite and stable rules of

\footnotetext{
${ }^{35}$ Friedman (1960, p. 81) argued similarly: "A full-fledged gold standard ... would have the great merits of complete automatically and of freedom from government control. It would be costly in terms both of the resources used to mine gold and of the price movements resulting from the relative cost of producing gold and other commodities." See, also, Friedman (1953, pp. 178-79).
} 
the game, especially as to money.... To put our present problem as a paradox -we need to design and establish with the greatest intelligence a monetary system good enough so that, hereafter, we may hold to it unrationally -- on faith -- as a religion, if you please. The utter inadequacy of the old gold standard, either as a definite system of rules or as the basis of a monetary religion, seems beyond intelligent dispute (italics added, 1936, p. 169).

Price-level stability. Director argued that the main advantage of a rule that aims to stabilize the price level is that it is easy to comprehend. Its disadvantages are: (1) it introduces "a considerable amount of discretion with respect to the timing and magnitude of the operations of the monetary authority" and (2) "it introduces the problem of the definition of the price level" (p. 6). Friedman (1960, p. 87) provided a similar assessment of the use of price stability as a policy guide: "Entirely aside from the technical problem of the specific index number of prices that should be used, the key difficulty is that the link between price changes and monetary changes over short periods is too loose and too imperfectly known to make price level stability an objective and reasonably unambiguous guide to policy." 36

Fixed-quantity of money. Director stated that a rule that fixes the quantity of money was "the original position of the so-called Chicago view or Chicago School, which is essentially the work of Henry Simons" (p. 6). A "great advantage" of such a rule is that it is easily understood. The early-1930s Chicagoans, he noted, combined their advocacy of a policy rule with the 100 percent reserves proposal:

In the original formulation of the fixed-quantity-of-money rule or the stablelevel-of-prices rule, great importance was attached to the reorganization of the banking structure, which is really a different thing from the rule adopted. This is the part of the formulation which has received most criticism. If it had not been incorporated in the original scheme, the scheme [i.e., policy rule] itself might have received a lot more support. Why this should be I have never known except the fact that we seem to believe that everything we have must be the result of natural forces and any drastic change [such as] that embodied in the 100 percent reserve banking scheme suspect (pp. 6-7).

\footnotetext{
${ }^{36}$ Friedman's argument was based on a 1951 paper showing that the existence of long and variable lags associated with discretionary policies can amplify the business cycle. See Friedman (1951a).
} 
Director then discussed the rationale underlying the 100 percent scheme. In common with the argument made in the November 1933 memorandum, he argued that the scheme aimed to prevent the "possible loss of confidence in banks [during] unfavorable conditions which would lead to striking changes in the supply of money" (p. 7). One key development had taken place, however, after November 1933 that reduced the possibility of a loss in confidence in banks: "At the time [that] this proposal was first made we didn't have an insurance system for banking. Now [with deposit insurance] this [reason for the 100 percent scheme] has been largely eliminated" (pp. 7-8).

Director also provided an argument in favor of the 100 percent reserves scheme not contained in the November 1933 memorandum -- "the choice between fractional reserves and 100 percent reserves depends on the extent to which we want to rely on discretionary authorities" (p. 8). The argument ran as follows. Suppose, as Director did, that monetary policy followed a growth-rate rule: "With 100 percent reserve banking, all the authorities would have to do is to make certain that they, themselves, created the necessary addition, say, to the quantity of money." Under a fractional reserve system, in contrast, the authorities would have to "create that amount of reserves which they thought would carry with it the necessary increase in the quantity of money." Therefore, "if the fractional reserve system responded in different ways over [different] periods of time to the level of reserves, then the monetary authorities would have to be given some discretion in determining the increase in the level of reserves in order to accomplish the final increase in the total quantity of money" (p. 8). Director concluded his assessment of the 100 percent reserves scheme as follows: "there is still a great to be said for working in the direction of a banking system with 100 percent reserves; but, it is not nearly as crucial a factor as we once considered it" (p. 8).

During the question-and-answer question toward the end of the presentation, a member from the audience, whom Director identified as "Professor Hayek," asked the following question: "What would happen under a 4 percent annual money-growth rule if the level of prices suddenly went up, by 10 percent or 15 percent? Then the monetary authorities are no longer in there" [i.e., are not able to act in a discretionary way to reduce inflation]. Director's response was: "But our position [is that] these things will not happen in such a [rules-based] system. But this is an empirical issue" (p. 12).

Three final points about arguments made by Director in the lecture are important. First, Director expressed the view that the emerging empirical evidence indicated that 
the "primary source of instability [in the economy] has not been ... changes in preferences [with regard to consumption and investment], but the primary source has been changes in the quantity of money" (p. 10). With Friedman and his collaborators having been the main producers of that evidence, Director's view on the role of money in the economy had clearly been influenced by the work of Friedman. Second, in stating his preference for rules over discretion, Director stated: "a necessary implication of an independent national monetary policy is for free, flexible exchange rates" (p. 6). As mentioned, the view that a flexible exchange-rate regime is needed to conduct domestic monetary policy was a characteristic that marked the 1930s tradition; that view also marked Friedman's (1948; 1953) work. Third, in response to the question: "How would you modify the Fed?," Director replied: "the first thing to do is abolish it and substitute a rule under which the money supply would increase by 2 percent or 3 percent per year" (p. 12). In a December 5, 1981 interview in Human Events, Friedman stated "I have been in favor of abolishing the Federal Reserve System for as long as I can remember" (quoted from Nelson 2020, Chapter 8, p. 435). ${ }^{37}$

\section{IV.5. Discussion}

As mentioned, the key elements of Friedman's monetarism emerged during the period from the late-1940s to the mid-1950s. In 1948, Friedman held the following views. (1) In line with the early-1930s Chicago approach that changes in the quantity of money be effectuated through the government's fiscal position, he proposed a rule under which fiscal policy would be used to implement changes in the money supply. The stock of money would be increased when there was an increase in the budget deficit -- by the amount of the deficit; it would be decreased when there was a surplus in the federal budget -- by the amount of the surplus (Friedman 1948, p. 145). (2) To deal with what Friedman regarded as the "inherent instability" of a fractional reserve banking system, Friedman called for 100 percent reserve requirements against demand deposits.

On the basis of his research -- both his own and that with his collaborators, especially Anna Schwartz -- by the mid-1950s Friedman's views on 100 percent reserves

\footnotetext{
${ }^{37}$ I am grateful to Ed Nelson for providing me with this information. Nelson (2020, Chapter 8, p. 435) also provides the following remark made in 1964 by George Stigler which collaborated Friedman's claim that he had long-held the view that the Fed should be abolished: "My colleague, Milton Friedman, on occasion recommends the abolition of the Federal Reserve System." The remark was made in Ketchum and Strunk (1964, p. 42).
} 
and on the appropriate rule had changed; he no longer considered a fractional-reserve banking system to be a potent force in the business cycle (1954; 1960, Chapter 3). An important reason underlying his changed view was the establishment of the Federal Deposit Insurance Corporation which, he believed, strengthened the resilience of the banking system $(1954$, p. $60 ; 1960$, p. 67). Nevertheless, Friedman continued to support the 100 percent reserves scheme throughout his career and, in doing so, gave credit to his teachers Simons and Mints for having earlier proposed the scheme (1960, p. 65). His support for the scheme was based on two arguments. First, he believed that "federal insurance of deposits involves a substantial increase in government intervention into the lending and investing process" (1960, pp. 67-68); in contrast, the 100 percent reserves scheme would ensure the safety of deposits while also reducing the rationale for government intervention. Second, "decisions by holders of money about the form in which they want to hold money and by banks about the structure of their assets tend to affect the amount available to be held. This has often been referred to as the inherent instability' of a fractional reserve system" (1960, p. 66). The 100 percent reserves scheme, Friedman argued, would provide improved control over the quantity of money compared with the fractional-reserve system. ${ }^{38}$

In a lecture delivered in 1956, Friedman stated that he had come to believe that his earlier proposal that the Federal budget be used to control the money-supply to be "more sophisticated than is necessary" (1956b, p. 5). In its place, he proposed -- for the first time in public -- a money-growth rule under which the money supply would increase by four percent per year (Friedman 1956b, p. 7). Thus, by the mid-1950s both Director and Friedman had reached similar views on (1) the important role played by money in driving economic activity, (2) the role of the Fed in the Great Depression, (3) the need of a money-growth rule, (4) the need of flexible exchange rates, and (5) the assessment that 100 percent reserve requirements would be a desirable, but, because of the advent

\footnotetext{
${ }^{38}$ In contrast to Simons, in the 1950s Friedman did not argue that the fractional-reserve system can lead to cumulative changes in velocity and, thus, to financial crises. However, in the aftermath of the savings and loan crisis in the United States in the early-1990s, in the preface to the $10^{\text {th }}$ edition of his 1960 book (comprising his 1959 Fordham lecture) he stated "Had it [the 100 percent reserves proposal] been adopted, the savings and loan crisis and the crisis threatening the FDIC could not have arisen. Unfortunately, the proposal was completely neglected for decades. More recently, it has been revived under a new name, narrow banking ... I very much fear that the revived version is no more likely to be adopted that the earlier" (1960, 1992 edition, p. x). Nelson (2013) discussed Friedman's views on financial stability.
} 
of deposit insurance, not crucial, factor for the financial system. On points (1) and (2), Director had clearly been influenced by Friedman's research showing the role played by changes in the quantity of money in driving the business cycle in general, and the Great Depression in particular. ${ }^{39}$

\section{CONCLUDING REMARKS}

In the early-1970s Friedman was accused of "invented" an oral Chicago quantitytheory tradition. The accusation was motivated by Don Patinkin's (1969) work demonstrating that the theoretical frameworks used by the early-1930s Chicagoans and by Friedman were different. Based on Patinkin's work, Harry Johnson argued that, to create a successful monetarist counter-revolution, Friedman faced the "problem of establishing ... a plausible linkage with pre-Keynesian orthodoxy," a problem that Friedman solved, according to Johnson, with "the invention of University of Chicago oral tradition that was alleged to have preserved the fundamental truth among a small band of the initiated through the dark years of the Keynesian despotism" (1971, pp. 1011). ${ }^{40}$

This paper has presented evidence -- much of it for the first time in the literature -on the monetary views of Aaron Director in the early-1930s and the mid-1950s, both of which were crucial stages in the development of Chicago monetary economics. Director interacted closely with Simons in the earlier period and, at a time when the economics profession downplayed the role of monetary forces in the economy, with Friedman in the later period. Director transmitted -- and perhaps contributed to -- key ideas that marked the earlier Chicago quantity-theory tradition including the views that: (i) the quantity of money matters, both as a counter-cyclical tool and for the maintenance of

\footnotetext{
${ }^{39}$ Recall that during the early-1930s Director had not formulated clear-out analysis about the origination of the cycle. Recall, also, that in the early-1930s Douglas and Director had advocated a monetary growthrate rule.

${ }^{40}$ Friedman (1971) considered Johnson's remarks to be "libelous." The view that Friedman had invented a Chicago quantity-theory tradition has been widely accepted by doctrinal historians. Moggridge and Howson (1974, p. 227) wrote: “The ... famous oral tradition, of Chicago, has been shown by Patinkin to be a mythical invention.” See, also, Laidler (1973), Howson (2005, p. 388), Dimand (2010, p. 77), and Backhouse (2013, p. 346). Recent work supporting Friedman's claim that his monetary economics derived from an earlier Chicago quantity-theory tradition includes Tavlas (2019b) and Dellas and Tavlas
} (2019). 
long-term stability; (ii) rules are necessary to reduce policy uncertainty and maintain economic stability; (iii) the Fed precipitated the Great Depression; (iv) the need of flexible exchange rates; and (v) 100 percent reserves are desirable. Each of these characteristics was put forward in published work by Simons before his death in 1946, by Mints until his retirement in 1953, by Director in the mid-1950s, and by Friedman beginning in the 1950s. With very few exceptions, these views were not held by any economist outside of Chicago in the 1940s and 1950s. ${ }^{41}$

In May 1967, Friedman delivered the third in a series of "Henry Simons Lectures" at the University of Chicago Law School. The title of Friedman's lecture was "The Monetary Theory and Policy of Henry Simons." Friedman described Simons as "above all, a shaper of my ideas" (Friedman 1967, p. 55). The introduction to Friedman's presentation was made by Director. In his unpublished introduction, Director made a statement that affirmed his belief in the existence of a Chicago monetary tradition: "One of the fields which Henry Simons cultivated was that of monetary theory and policy. That he did so accounts in no small measure for the continued interest in, and cultivation of, this subject at the University of Chicago, while it languished elsewhere" (Director 1967, p. 3). That Director also cultivated that field accounts in no small measure for the continued interest in monetary theory and policy at the University of Chicago and for the continuity between the monetary framework of Chicago of the early-1930s and that of Chicago of the 1950s and after.

\section{Acknowledgements}

I have benefited from comments from the editor, Pedro Duarte, two referees, and Harris Dellas, David Friedman, Ed Nelson, George Selgin, Stephen Stigler, and Michael Ulan. I thank Sarah Patton and the other members of the staff at the Hoover Institution Library \& Archives for their assistance. I thank Elisavet Bosdelekidou and Maria Monopoli for research support.

\footnotetext{
${ }^{41}$ The major exception was Clark Warburton, who in the 1940s argued that changes in the money supply were the driving force in the business cycle and that the Fed precipitated the Great Depression. Warburton advocated a monetary-growth rule, but did not support 100 percent reserves. On Warburton's contributions, see Humphrey (1971), Bordo and Schwartz (1979), and Tavlas (2019b). On Simons's views, see, Tavlas (2015); on Mints's views, see Dellas and Tavlas (2019).
} 


\section{REFERENCES}

Backhouse, Roger E. (2013). "Review of Ross B. Emmett, ed., The Elgar Companion to the Chicago School of Economics and Philip Mirowski, Thomas A. Stapleford, and Robert Van Horn, eds., Building Chicago Economics: New Perspectives on the History of America's Most Powerful Economics." History of Political Economy 45 (2): 245349.

Bordo, Michael and Schwartz, Anna. 1979. "Clark Warburton: Pioneer Monetarist." Journal of Monetary Economics 5: 43-65.

Coase, Ronald. 1998. "Director, Aaron.” In Peter Newman, ed., The New Palgrave Dictionary of Economics and The Law, Volume 1. London: MacMillan, pp. 601-05.

Davenport, John. 1964. The U.S. Economy. Washington, D.C.: Regnery Publishing.

Dellas, Harris and Tavlas, George S. 2019. "The Dog that Didn't Bark: The Curious Case of Lloyd Mints, Milton Friedman and the Transformation of the Chicago Quantity-Theory Tradition.” CEPR Discussion Paper 13858 July. Forthcoming in History of Political Economy.

Dimand, Robert W. 2010. "David Laidler's Contributions to the History of Monetary Economics.” In Robert Leeson, ed., David Laidler's Contributions to Economics. London: Palgrave Macmillan, pp. 60-84.

Director, Aaron. 1932. Unemployment. Chicago: American Library Association.

Director, Aaron. 1933. The Economics of Technocracy. Chicago: University of Chicago Press.

Director, Aaron. 1940. "Does Inflation Change the Economic Effects of War?” American Economic Review 30 (1): 351-61.

Director, Aaron. 1955a. Memorandum on Monetary Policy to John Davenport, 1, untitled, July 11.

Director, Aaron. 1955b. Memorandum on Monetary Policy to John Davenport, 2, untitled, July 29.

Director, Aaron. 1956. Lecture of Full Employment Policy. Institute of Humane Studies June 20 .

Director, Aaron. 1967. "Introduction for the Simons Lecture," unpublished, May 5.

Director, Aaron, et al. 1948. "Control of Prices; Regulation of Money Supply to Halt Inflation Advocated." The New York Times, January 11.

Douglas, Paul H. 1927. "The Modern Technique of Mass Production and its Relation to Wages." Proceedings of the Academy of Political Science 12 (July): 17-42. 
Douglas, Paul H., and Director, Aaron. 1931. The Problem of Unemployment. New York: MacMillan.

Douglas, Paul H. 1934. Letter to Chester C. Maxey, October 29.

Fisher, Irving, with Harry G. Brown. 1911. The Purchasing Power of Money. New York: Macmillan.

Federal Reserve Board. 1955. Forty-second Annual Report of the Board of Governors of the Federal Reserve System. Covering operations for the year 1955.

Friedman, Milton. 1948. “A Monetary and Fiscal Framework for Economic Stability." Reprinted in Milton Friedman, ed., Essays in Positive Economics. Chicago: University of Chicago Press, 1953, pp. 133-56.

Friedman, Milton. 1951a. "The Effects of a Full-employment Policy on Economic Stability: a Formal analysis.” Reprinted in Milton Friedman, ed., Essays in Positive Economics. Chicago: University of Chicago Press, 1953, pp. 117-56.

Friedman, Milton. 1951b. "Commodity-Reserve Currency." Journal of Political Economy 59 (3): 203-32.

Friedman, Milton. 1953. "The Case for Flexible Exchange Rates.” Reprinted in Essays in Positive Economics, edited by Milton Friedman (1953). Chicago: University of Chicago Press, 157-203.

Friedman, Milton. 1954. "Why the American Economy is Depression Proof." Nationalekonomiska Föreningens Förhandlingar 3: 58-77. Reprinted in Milton Friedman, ed., Dollars and Deficits: Living with America's Economic Problems. Englewood Cliffs, N.J.: Prentice Hall, 1968, pp. 72-96.

Friedman, Milton. 1956a. “The Quantity Theory of Money: A Restatement.” In Milton Friedman, ed., Studies in the Quantity Theory of Money. Chicago: University of Chicago Press, pp. 3-21.

Friedman, Milton. 1956b. "Monetary Policy, Domestic and International.” Unpublished lecture delivered at Wabash College on June 19. Available at: http://miltonfriedman.hoover.org/friedman_images/Collections/2016c21/MFlecture _ 6_1956_4.pdf

Friedman, Milton. 1960. Program for Monetary Stability. New York: Fordham University Press.

Friedman, Milton. 1967. "The Monetary Theory and Policy of Henry Simons." The Journal of Law and Economics 10: 1-13. Reprinted in Milton Friedman, ed., The Optimum Quantity of Money and Other Essays. Chicago: Aldine, 1969, pp. 111-39. 
Friedman, Milton. 1981. "Exclusive Interview: Milton Friedman on Reaganomics." Human Events, 51 (49): 1 and 6-9.

Friedman, Milton. 1992. "Preface." In Milton Friedman, A Program for Monetary Stability. Fordham, N.Y.: Fordham University Press, pp. vii-xii.

Friedman, Milton. 1996. Letter to David Laidler, October 9.

Friedman, Milton and Friedman, Rose D. 1998. Two Lucky People. Chicago: University of Chicago Press.

Friedman, Milton and Schwartz, Anna J. 1963. A Monetary History of the United States, 1867-1960. Princeton, N.J.: Princeton University Press.

Hart, Albert G. 1935. "The 'Chicago Plan 'of Banking Reform.” Review of Economic Studies 2 (February): 104-16.

Hayek, Friedrich. 1946. Letter to Aaron Director, July 10 (quoted from Van Horn, 2010, p. 267).

Hayek, Friedrich. 1960. The Constitution of Liberty. Chicago: University of Chicago Press.

Howson, Susan. 2005. "Review of Keynes, Chicago, and Friedman." History of Political Economy 37 (2): 386-391.

Humphrey, Thomas. 1971. "Role of Non-Chicago Economists in the Evolution of the Quantity Theory in America, 1930-50.” Southern Economic Journal 38: 12-18.

Johnson, Harry G. 1971. "The Keynesian Revolution and the Monetarist CounterRevolution." American Economic Review 61 (2): 1-14.

Kitch, Edmund W. 1983. "The Fire of Truth: A Remembrance of Law and Economics at Chicago, 1932-1970" The Journal of Law and Economics 26 (1): 163-234.

Ketchum, Marshall D. and Strunk, Norman (eds.) 1964. Proceedings of the Conference on Savings and Residential Financing: 1964 Proceedings, May 7 and 8, 1964, Chicago, Illinois. Chicago: United States Savings and Loan League.

Knight, Frank H. et al. 1933. Untitled memoranda, March 15.

Laidler, David. 1973. "Review of Don Patinkin, ed., Studies in Monetary Economics." The Economic Journal 83 (329): 262-264.

Leeson, Robert, ed. 2003. Keynes, Chicago and Friedman, 2 vols. London: Pickering \& Chatto.

Lothian, James R. and Tavlas, George S. 2018. "How Friedman and Schwartz Became Monetarists." Journal of Money, Credit and Banking 50 (4): 757-787. 
Meltzer, Allan H. 2009. A History of the Federal Reserve. Volume 2, Book 1, 1951-1969.

Chicago: University of Chicago Press.

Moggridge, D. E. and Howson, S. 1974. "Keynes on Monetary Policy, 1910-1946." Oxford Economic Papers 26: 226-47.

Nelson, Edward. 2009. "Milton Friedman and U.K. Economic Policy: 1938-1979." Review, Federal Reserve Bank of St. Louis September: 465-506.

Nelson, Edward. 2013. "Friedman's Monetary Economics in Practice." Journal of International Money and Finance 38 (C): 59-83.

Nelson, Edward. 2020. Milton Friedman and Economic Debate in the United States, 1932 - 1972. Chicago: University Chicago Press.

Patinkin, Don. 1969. "The Chicago Tradition, the Quantity Theory, and Friedman." Journal of Money, Credit and Banking 1: 46-70.

"Pettengill Memorandum." 1932. "Payment of Adjusted-Compensation Certificates." Hearings before the Committee on Ways and Means, House of Representatives, April 11 to 29. Washington, D.C.: United States Government.

Phillips, Ronnie J. 1995. The Chicago Plan and New Deal Banking Reform. New York:

M.E. Sharpe.

Reder, Melvin W. 1982. “Chicago Economics: Permanence and Change.” Journal of Economic Literature 20 (1): 1-38.

Samuelson, Paul A. 1995. Letter to Milton Friedman, December 8.

Selgin, George. 1999. "Hayek versus Keynes on How the Price Level Ought to Behave." History of Political Economy 31 (4): 699-721.

Simons, Henry C. 1934. Letter to Paul Douglas. October 2.

Simons, Henry C. 1936. "Rules versus Authorities in Monetary Policy." Journal of Political Economy 64: 1-30. Reprinted in Henry Simons, Economic Policy for a Free Society. Chicago: University of Chicago Press, 1948, pp. 160-83.

Simons, Henry C. 1939. Letter to Chester Wright. February 20.

Simons, Henry C. et al. 1933. "Banking and Currency Reform," including Appendix, "Banking and Business Cycles," and Supplementary Memorandum, "Long-term Objectives of Monetary Management." Unsigned mimeograph. Department of Economics, University of Chicago.

Stigler, Stephen. 2005. "Aaron Director Remembered." The Journal of Law and Economics 48 (2): 307-311.

Tavlas, George S. 1997. "Chicago, Harvard, and the Doctrinal Foundations of Monetary 
Economics.” Journal of Political Economy 105 (1): 153-177.

Tavlas, George S. 2015. "In Old Chicago: Simons, Friedman, and the Development of Monetary-Policy Rules.” Journal of Money, Credit and Banking 47 (1): 99-121.

Tavlas, George S. 2019a. “"The Group': The Making of the Chicago Monetary Tradition, 1927-36." History of Political Economy 51 (2): 259-96.

Tavlas, George S. 2019b. "The Intellectual Origins of the Monetarist Counter-revolution Reconsidered: How Clark Warburton Influenced Milton Friedman's Monetary Thinking." Oxford Economic Papers 71 (3): 645-65.

Tavlas, George S. 2019c. "A Reconsideration of the Doctrinal Foundations of Monetary-

Policy Rules: Fisher versus Chicago." Forthcoming in Journal of the History of Economic Thought.

Tavlas, George S. 2020. “On the Controversy Over the Origins of the Chicago Plan for 100 Percent Reserves: Sorry Frederick Soddy, it was Knight and (Most Probably) Simons!," Hoover Institution Economics Working Paper 20102. Forthcoming in Journal of Money, Credit and Banking.

University of Chicago News Office. 2004. Aaron Director, Founder of the Field of Law and Economics. Available at:

http://www-news.uchicago.edu/releases/04/040913.director.shtml

Van Horn, Robert. 2010a. "Aaron Director." In Ross B. Emmett, ed., The Elgar Companion to the Chicago School of Economics. U.K.: Edward Elgar Publishing, pp. 265-69.

Van Horn, Robert. 2010b. "Harry Aaron Director: The Coming of Age of a Reformer Skeptic (1914-24).” History of Political Economy 42 (4): 601-30.

Van Horn, Robert. 2014. “Henry Simons's Death.” History of Political Economy 46 (3): 525-35.

White, Lawrence H. 1999. "Hayek's Monetary Theory and Policy: A Critical Reconstruction.” Journal of Money, Credit and Banking 31 (1): 109-20. 